\title{
Medicine and History
}

\section{QUANTIFICATION AND THE QUEST FOR MEDICAL CERTAINTY}

\section{J. Rosser Matthews}

Since its inception in World War II, the clinical trial has evolved into a standard procedure in determining therapeutic efficacy. However, the use of comparative statistics in a therapeutic context has a much longer history. Here J. Rosser Matthews discusses three crucial debates: that among clinicians before the Parisian Academy of Medicine in 1837 , the debate in the German physiological literature during the 1850s, and, in the early twentieth century, the debate over the bacteriologist's diagnostic technique involving the "opsonic index."

Matthews demonstrates that despite the differences separating clinician, physiologist, and bacteriologist, they all shared an antipathy toward the methods of the statistician. Only when "medical decision-making" moved from the cloistered confines of professional medical expertise into the arena of open political debate could the medical statistician (and the clinical trial) gain the upper hand.

"A perceptive book.... A most illuminating study. ... "-Roy Porter, Nature

"An extremely thorough, revealing, and well-written account of the long-standing fight between the numerate and the innumerate; between those who saw themselves as down-to-earth practical doctors and those regarded by such men as airy-fairy theorists.

..."-Irvine Loudon, The Lancet

Cloth: f32.00 ISBN 0-691-03794-9

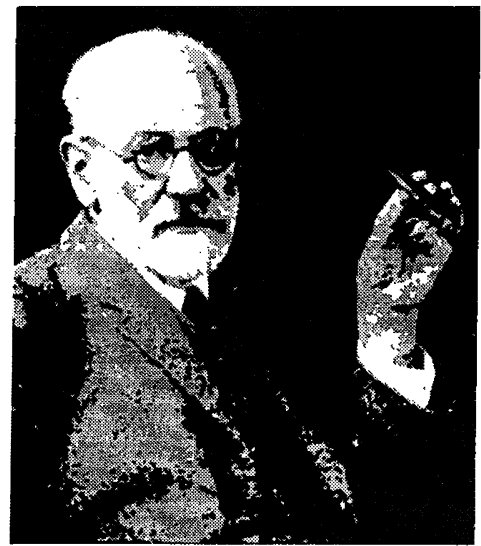

\section{New in paperback FREUD, RACE, AND GENDER}

\section{Sander L. Gilman}

"... the most convincing account of how Freud's anxiety about being Jewish is reflected in his work." -Howard Eilberg-Schwartz, New York Times Book Review

"Gilman [is] one of the most original and stimulating cultural historians of his generation."

-New Statesman \& Society

“... original and penetrating. . . display[s] all the familiar hallmarks of Gilman's formidable scholarship. ... richly erudite in the small print of medico-scientific writings of the fin-de-siecle era, showing Freud as a child of his times."-Roy Porter, The New Republic Now in paper: $£ 10.95$ ISBN 0-691-02586-X Available February 1996

\section{PRINCETON UNIVERSITY PRESS}

AVAILABLE FROM YOUR BOOKSELLER OR DIRECTLY FROM THE PUBLISHER: (609) 883-1759 U.S. (1243) 779777 U.K./EUROPE • WORLD WIDE WEB SITE: HTTP: /IAAUP.PUPRESS.PRINCETON.EDU/PUPRESS 
Rare Books \& Manuscripts in the history of

Medicine $\mathcal{E}$ the Sciences

Bought $\bullet$ Sold $\bullet$ Appraised

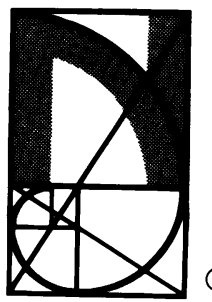

尺

Send for our latest catalogue Jeremy Norman \& Co., Inc.

720 Market Street

San Francisco, California 94102

(415) 781-6402

FAX (415) 781-5507

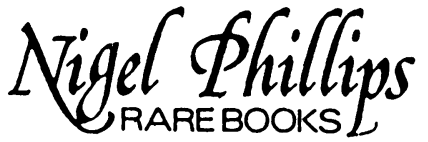

Antiquarian books in the history of medicine and the health sciences.

Please send for my catalogue, or telephone for an appointment when in London.

5 BURLEIGH PLACE PUTNEY

LONDON SW15 6ES

ENGLAND

Tel: 01817882664

Fax: 01817801989

\section{Books concerning the}

History of Medicine, Natural, Pure and Applied Science

Catalogues issued—desiderata lists welcome

\section{MICHAEL PHELPS ANTIQUARIAN BOOKS}

9 CHELVERTON ROAD - PUTNEY LONDON SW15 1RN - ENGLAND Telephone: 0181-785 6766 Fax: 0181-785 6944

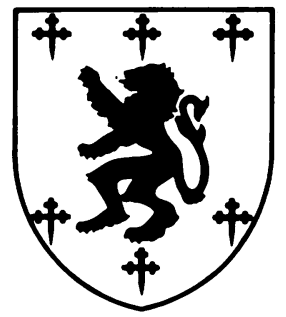

